\title{
Tall Fescue and Perennial Ryegrass Reseeding Intervals for Amicarbazone
}

\author{
Patrick E. McCullough ${ }^{1,3}$ \\ Department of Crop and Soil Sciences, University of Georgia, 1109 \\ Experiment Street, Griffin, GA 30223-1797
}

\author{
James T. Brosnan ${ }^{1}$ and Gregory K. Breeden ${ }^{2}$ \\ Department of Plant Sciences, University of Tennessee, Knoxville, TN 37996
}

Additional index words. establishment, annual bluegrass, herbicide

\begin{abstract}
Turf managers applying amicarbazone for annual bluegrass (Poa annua L.) control in cool-season turfgrasses may wish to reseed into treated areas. Field experiments were conducted in Georgia and Tennessee to investigate perennial ryegrass (Lolium perenne L.) and tall fescue (Festuca arundinacea Schreb.) reseeding intervals after amicarbazone applications. Perennial ryegrass and tall fescue cover were reduced similarly (less than $10 \%$ from the untreated) by all herbicides applied 2, 4, or 6 weeks before seeding. Bispyribac-sodium at $0.1 \mathrm{~kg}$ a.i./ha reduced tall fescue and perennial ryegrass cover more than amicarbazone at 0.1 or $0.2 \mathrm{~kg}$ a.i./ha when applied the day of seeding. Applied on the day of seeding in Georgia, amicarbazone at $0.4 \mathrm{~kg} \cdot \mathrm{ha}^{-1}$ reduced turf cover of each species similar to bispyribac-sodium; however, this response was not observed in Tennessee. Results suggest tall fescue and perennial ryegrass can be safely seeded the day of amicarbazone applications at 0.1 or $0.2 \mathrm{~kg} \cdot \mathrm{ha}^{-1}$, but practitioners may need to wait 2 weeks before seeding these turfgrasses into areas treated with amicarbazone at $0.4 \mathrm{~kg} \cdot \mathrm{ha}^{-1}$ or bispyribac-sodium at $0.1 \mathrm{~kg}$ a.i./ha.
\end{abstract}

Annual bluegrass (Poa annua L.) is a problematic weed that reduces turfgrass aesthetics, functionality, and surface quality (Beard, 1970). Compared with most turfgrasses, annual bluegrass has a lighter green color, shallow root system, and produces unsightly seedheads (Lush, 1989; Sprague and Burton, 1937). Annual bluegrass tolerates close mowing, germinates rapidly, and has undesirable qualities, including poor disease, drought, and wear tolerance that can reduce turf quality (Beard et al., 1978; Kaminski and Dernoeden, 2007; Lush, 1989). Consequently, turf infested with annual bluegrass requires increased water, fungicides, and intensive management to maintain acceptable quality, especially in the summer months.

Annual bluegrass can be selectively controlled in creeping bentgrass (Agrostis stolonifera L.), perennial ryegrass (Lolium perenne L.), and tall fescue (Festuca arundinacea Schreb.) with an acetolactate synthase inhibitor, bispyribac-sodium (Lycan and Hart, 2005a, 2006a; McCullough and Hart, 2009). Although highly active on annual bluegrass in warm weather $\left(20^{\circ} \mathrm{C}\right.$ or higher $)$, bispyribacsodium efficacy is often reduced under cool temperatures $\left(20^{\circ} \mathrm{C}\right.$ or less), which may limit application timings in spring (Lycan and Hart, 2006a; McCullough and Hart, 2006).

Received for publication 6 Aug. 2009. Accepted for publication 20 Sept. 2010.

${ }^{1}$ Assistant Professor.

${ }^{2}$ Extension Specialist.

${ }^{3}$ To whom reprint requests should be addressed; e-mail pmccull@uga.edu.
Ethofumesate, mesotrione, and sulfosulfuron have activity on young annual bluegrass plants, but limitations of tolerant turf species, inconsistent efficacy, and required application regimes restrict the potential for these herbicides to be used for annual bluegrass control in cool-season turfgrasses (Hart and McCullough, 2009; Johnson et al., 1989; Lycan and Hart, 2005b, 2006a; Lycan et al., 2005).

Application timing of postemergence herbicides for annual bluegrass control has been reported to influence establishment of turfgrasses from seed. Lycan and Hart (2006b) noted reductions in creeping bentgrass, kentucky bluegrass (Poa pratensis L.), and perennial ryegrass seedling cover from bispyribac-sodium applied 1 week before seeding (WBS), but these grasses were safely established when herbicides were applied 2 WBS. Common bermudagrass (Cynodon dactylon L.) seedlings have shown significant injury and reduced establishment from rimsulfuron, simazine, and trifloxysulfuron applied 1 to 2 WBS (McCullough and Nutt, 2010; Willis et al., 2007). Furthermore, researchers noted sulfosulfuron at 13 to $26 \mathrm{~g} / \mathrm{a}$.i./ha applied the day of seeding or 1 WBS significantly reduced creeping bentgrass and kentucky bluegrass establishment from the untreated. Thus, reseeding intervals may be critical for new herbicides introduced for postemergence annual bluegrass control in turf management regimes.

Amicarbazone is a photosystem IIinhibiting herbicide used for broadleaf weed control in corn (Zea mays L.) and sugarcane (Saccharum officinarum L) production (Senseman, 2007). Amicarbazone has soil residual activity, but postemergence applications also control susceptible weeds (Senseman, 2007). Field experiments have noted that sequential amicarbazone applications in spring of 0.1 to $0.4 \mathrm{~kg} \cdot \mathrm{ha}^{-1}$ effectively controlled annual bluegrass without causing unacceptable injury (greater than 20\%) to creeping bentgrass, kentucky bluegrass, perennial ryegrass, and tall fescue (McCullough et al., 2010; Yelverton, 2008). Amicarbazone may also have greater efficacy than acetolactate synthase inhibitors such as bispyribacsodium when applied during cooler weather in late winter or early spring, which may provide new options to end-users for selective annual bluegrass control in cool-season turf (McCullough et al., 2010).

Turfgrass managers may need to reseed desirable turfgrasses into voids remaining after annual bluegrass has been eradicated by amicarbazone or other postemergence herbicides. However, the soil residual activity of amicarbazone may inhibit turfgrass seedling establishment. Therefore, the objective of this research was to determine reseeding intervals for tall fescue and perennial ryegrass after amicarbazone applications.

\section{Materials and Methods}

Experiments were conducted from March to June 2010 in Griffin, GA, and Knoxville, TN. Soil in Georgia was a Cecil sandy loam with $2 \%$ organic matter and $\mathrm{pH}$ of 6.4 . Soil in Tennessee was a Sequatchie loam soil (fineloamy, siliceous, semiactive, thermic humic Hapludult) with $2.1 \%$ organic matter and a 6.2 soil $\mathrm{pH}$. Experiments were initiated on mature tall fescue fields at both locations. Irrigation at both locations was applied to prevent wilt and sites were mowed weekly with a rotary mower at $6.4-\mathrm{cm}$ height with clippings returned.

Experimental design. Separate studies were conducted to determine reseeding intervals for tall fescue and perennial ryegrass. The experimental design for each site was a randomized complete block with four replications. Four herbicide treatments were applied at four application timings before seeding in addition to an untreated control. Amicarbazone (70 WG; Arysta LifeSciences LLC, Cary, $\mathrm{NC)}$ was applied at $0.1,0.2$, or $0.4 \mathrm{~kg}$ a.i./ha and bispyribac-sodium (Velocity 17.6 WDF; Valent USA Corp., Walnut Creek, CA) was applied at $0.1 \mathrm{~kg}$ a.i./ha. Herbicide treatments were applied 0, 2, 4, or 6 WBS. Application dates in Georgia and Tennessee are presented in Table 1. Amicarbazone rates were selected from previous research evaluating broadcast applications of amicarbazone for selective annual bluegrass control (McCullough et al., 2010; Yelverton, 2008). The bispyribacsodium rate was selected from label recommendations (Anonymous, 2004). A broadcast glyphosate (Roundup Pro; Monsanto Company, St. Louis, MO) application was made at $2.2 \mathrm{~kg}$ a.i./ha $7 \mathrm{~d}$ before seeding (DBS) to kill existing vegetation and facilitate visual assessment of turfgrass seedling cover. 
Treatments were applied to $1 \times 1.8-\mathrm{m}$ plots in Georgia and Tennessee. In Georgia, treatments were applied by making two passes in opposite directions with a single-nozzle (Teejet 9504E flat fan spray nozzle; Spraying Systems Co., Roswell, GA) $\mathrm{CO}_{2}$-pressured sprayer calibrated to deliver $375 \mathrm{~L} \cdot \mathrm{ha}^{-1}$. In Tennessee, treatments were applied by making one pass per plot with a four-nozzle (Teejet 8002 flat fan spray nozzle; Spraying Systems Co.) $\mathrm{CO}_{2}$-pressured sprayer calibrated to deliver $280 \mathrm{~L} \cdot \mathrm{ha}^{-1}$.

Turfgrass seeding and maintenance. On the day of seeding, the field was scalped to $3.8 \mathrm{~cm}$ with a rotary mower, debris was removed, and the seedbed received two additional passes with a vertical mower set to a depth of $\approx 1.3 \mathrm{~cm}$. Tall fescue (Titan tall fescue; Seed Research of Oregon, Inc., Corvallis, OR) and perennial ryegrass (Manhattan IV perennial ryegrass; Pure Seed Testing, Inc., Hubbard, OR) were seeded perpendicular to herbicide treatments overall plots at 390 $\mathrm{kg} \cdot \mathrm{ha}^{-1}$ with a drop spreader. Herbicide treatments scheduled for the day of seeding were applied immediately after seeding each turf species. After seeding, tall fescue and perennial ryegrass plots were irrigated daily to promote germination and establishment. A 10-10-10 (N- $\left.\mathrm{P}_{2} \mathrm{O}_{5}-\mathrm{K}_{2} \mathrm{O}\right)$ granular fertilizer was applied at $48 \mathrm{~kg} \mathrm{~N} / \mathrm{ha} \approx 4$ weeks after seeding (WAS) at each location.

Measurements and statistical analysis. Tall fescue and perennial ryegrass turf cover was assessed visually, because Yelverton et al. (2009) reported that visual ratings of herbicide responses in turf were highly correlated to those measured using the line intersect method or digital image analysis. Turf cover was evaluated for each species 2, 4, and 8 WAS on a percent scale in which 0 equaled no turf cover and 100 equaled complete turf cover in each plot. In Georgia, tall fescue and perennial ryegrass cover in untreated plots measured $56 \%$ and $65 \%$ by 4 WAS, respectively. By 8 WAS in Georgia, turf cover was difficult to rate as a result of the presence of crabgrass (Digitaria spp.) (greater than $30 \%$ of plot area) (data not shown). In Tennessee, turf cover in both the untreated tall fescue and perennial ryegrass plots measured $60 \%$ by 4 WAS and $100 \%$ by $8 \mathrm{WAS}$. Tall fescue and perennial ryegrass cover data collected on treated plots were converted to percent of the untreated control at each location.

Data were subjected to analysis of variance with main effects and all possible interactions

Table 1. Herbicide application and seeding dates in field experiments, 2010, in Griffin, GA (GA) and Knoxville, TN (TN).

\begin{tabular}{lrr}
\hline Application timing (WBS) & GA & \multicolumn{1}{c}{ TN } \\
\hline 6 & $1 \mathrm{Mar}$. & $1 \mathrm{Mar}$. \\
4 & $15 \mathrm{Mar}$. & $15 \mathrm{Mar}$. \\
2 & $30 \mathrm{Mar}$. & $30 \mathrm{Mar}$. \\
0 & $14 \mathrm{Apr}$. & $2 \mathrm{Apr}$. \\
& & \\
Glyphosate application & $6 \mathrm{Apr}$. & $5 \mathrm{Apr}$. \\
Seeding date & $14 \mathrm{Apr}$. & $12 \mathrm{Apr}$.
\end{tabular}

WBS $=$ weeks before seeding. tested using the appropriate expected mean square values as described by McIntosh (1983). Significant location-by-treatment interactions were detected for tall fescue and perennial ryegrass turf cover; thus, data from each location were analyzed and are presented individually. Fisher's protected least significant difference test was used to separate treatment means at the $P=0.05$ level.

\section{Results}

Tall fescue study. Tall fescue germination was noted by 2 WAS at each location but turf cover was minimal (data not shown). A treatment-by-timing interaction was detected in both Georgia and Tennessee by 4 WAS. At both locations, seedling tall fescue cover averaged $96 \%$ of the untreated control for herbicides applied 2, 4, or 6 WBS (Table 2). No significant differences in tall fescue cover were detected among amicarbazone or bispyribac-sodium treatments applied 2, 4, or 6 WBS (Table 2).

Significant reductions in tall fescue seedling cover were recorded 4 WAS at both locations for herbicide treatments applied the day of seeding. In Georgia, amicarbazone at $0.4 \mathrm{~kg} \cdot \mathrm{ha}^{-1}$ and bispyribac-sodium reduced tall fescue cover $46 \%$ and $57 \%$, respectively, when applied the day of seeding (Table 2). Amicarbazone treatments were similar and did not reduce tall fescue cover more than $15 \%$ from the untreated when applied at 0.1 or $0.2 \mathrm{~kg} \cdot \mathrm{ha}^{-1}$ at seeding.

Similar reductions in cool-season turfgrass establishment have been reported with amicarbazone. In North Carolina, amicarbazone at $0.5 \mathrm{~kg} \cdot \mathrm{ha}^{-1}$ reduced tall fescue cover when applied 0 or 2 DBS but treatments were safe when applied 12 or 17 DBS. In the same study, amicarbazone at $0.5 \mathrm{~kg} \cdot \mathrm{ha}^{-1}$ did not reduce creeping bentgrass cover at any timing (Yelverton, unpublished data). In Alabama, amicarbazone at $0.5 \mathrm{~kg} \cdot \mathrm{ha}^{-1}$ reduced creeping bentgrass stand density by $\approx 20 \%$ from the untreated control when applied at seeding but applications 8 DBS were safe (Walker, unpublished data).

Similar to what was observed in Georgia, bispyribac-sodium applied the day of seeding in Tennessee reduced tall fescue cover. In Tennessee, bispyribac-sodium reduced tall fescue cover (relative to the untreated control) $61 \%$ compared with only $17 \%$ for amicarbazone at $0.4 \mathrm{~kg} \cdot \mathrm{ha}^{-1}$ at $4 \mathrm{WAS}$. Lycan and Hart (2006b) reported a similar effect for bispyrabic-sodium applied 1 WBS creeping bentgrass, kentucky bluegrass, and perennial ryegrass. In contrast to what was observed in Georgia, no significant differences were detected among the three amicarbazone rates at 4 WAS in Tennessee. Tall fescue cover reductions after amicarbazone treatment ranged from $6 \%$ to $17 \%$ (Table 2). Similar responses were observed 8 WAS in Tennessee as well (Table 3).

Perennial ryegrass study. Although a direct statistical comparison was not made, treatment effects on perennial ryegrass establishment were similar to those observed on tall fescue at each location. Seedling perennial ryegrass cover averaged $96 \%$ of the untreated control for herbicides applied 2, 4 , or 6 WBS in both Georgia and Tennessee with no significant differences detected among amicarbazone or bispyribac-sodium treatments at these timings (Table 2).

Table 2. Effects of amicarbazone and bispyribac-sodium applications on 'Manhattan IV' perennial ryegrass and 'Titan' tall fescue groundcover at 4 weeks after seeding in field experiments in Griffin, GA (GA) and Knoxville, TN (TN)

\begin{tabular}{|c|c|c|c|c|c|c|}
\hline \multirow{4}{*}{$\begin{array}{l}\text { Timing } \\
\text { (WBS) }\end{array}$} & \multirow[b]{4}{*}{ Treatment } & \multirow{4}{*}{$\begin{array}{c}\text { Rate } \\
\text { (kg a.i./ha) }\end{array}$} & \multicolumn{4}{|c|}{ Turf cover } \\
\hline & & & \multicolumn{2}{|c|}{ GA } & \multicolumn{2}{|c|}{ TN } \\
\hline & & & P. ryegrass & $\overline{\text { Tall fescue }}$ & P. ryegrass & Tall fescue \\
\hline & & & \multicolumn{4}{|c|}{ Percent of untreated } \\
\hline \multirow[t]{5}{*}{$\overline{0}$} & Amicarbazone $^{z}$ & 0.1 & 94 & 85 & 94 & 83 \\
\hline & & 0.2 & 87 & 86 & 94 & 94 \\
\hline & & 0.4 & 58 & 54 & 94 & 83 \\
\hline & Bispyribac-sodium & 0.1 & 58 & 43 & 44 & 39 \\
\hline & & $\operatorname{LSD}_{0.05}$ & 16 & 21 & 17 & 18 \\
\hline \multirow[t]{5}{*}{2} & Amicarbazone & 0.1 & 96 & 87 & 100 & 100 \\
\hline & & 0.2 & 96 & 91 & 94 & 94 \\
\hline & & 0.4 & 103 & 93 & 94 & 88 \\
\hline & Bispyribac-sodium & 0.1 & 100 & 92 & 94 & 89 \\
\hline & & $\operatorname{LSD}_{0.05}$ & NS & NS & NS & NS \\
\hline \multirow[t]{5}{*}{4} & Amicarbazone & 0.1 & 98 & 88 & 100 & 100 \\
\hline & & 0.2 & 109 & 102 & 100 & 94 \\
\hline & & 0.4 & 108 & 96 & 100 & 100 \\
\hline & Bispyribac-sodium & 0.1 & 90 & 81 & 100 & 100 \\
\hline & & $\operatorname{LSD}_{0.05}$ & NS & NS & NS & NS \\
\hline \multirow[t]{8}{*}{6} & Amicarbazone & 0.1 & 98 & 94 & 100 & 100 \\
\hline & & 0.2 & 100 & 102 & 94 & 100 \\
\hline & & 0.4 & 95 & 93 & 100 & 100 \\
\hline & Bispyribac-sodium & 0.1 & 90 & 88 & 100 & 100 \\
\hline & & $\mathrm{LSD}_{0.05}$ & NS & NS & NS & NS \\
\hline & Treatment & & $*$ & $*$ & $*$ & $*$ \\
\hline & Timing & & $*$ & $*$ & $*$ & $*$ \\
\hline & Treatment $\times$ timing & & $*$ & NS & $*$ & $*$ \\
\hline
\end{tabular}

${ }^{\mathrm{z}}$ Amicarbazone treatments included a non-ionic surfactant at $0.25 \% \mathrm{v} / \mathrm{v}$.

$\mathrm{WBS}=$ weeks before seeding; $\mathrm{LSD}=$ least significant difference; $\mathrm{NS}=$ non-significant. 
Table 3. Effects of amicarbazone and bispyribac-sodium applications on 'Manhattan IV' perennial ryegrass and 'Titan' tall fescue groundcover at 8 weeks after seeding in field experiments in Knoxville, TN.

\begin{tabular}{|c|c|c|c|c|}
\hline \multirow{3}{*}{$\begin{array}{l}\text { Timing } \\
\text { (WBS) }\end{array}$} & \multirow[b]{3}{*}{ Treatment } & \multirow{3}{*}{$\begin{array}{c}\text { Rate } \\
\text { (kg a.i./ha) }\end{array}$} & \multicolumn{2}{|c|}{ Turf cover } \\
\hline & & & P. ryegrass & Tall fescue \\
\hline & & & \multicolumn{2}{|c|}{ Percent of untreated } \\
\hline \multirow[t]{5}{*}{$\overline{0}$} & Amicarbazone $^{z}$ & 0.1 & 100 & 98 \\
\hline & & 0.2 & 100 & 102 \\
\hline & & 0.4 & 98 & 97 \\
\hline & Bispyribac-sodium & 0.1 & 85 & 85 \\
\hline & & $\mathrm{LSD}_{0.05}$ & 6 & 7 \\
\hline \multirow[t]{5}{*}{2} & Amicarbazone & 0.1 & 100 & 100 \\
\hline & & 0.2 & 100 & 98 \\
\hline & & 0.4 & 102 & 102 \\
\hline & Bispyribac-sodium & 0.1 & 100 & 100 \\
\hline & & $\mathrm{LSD}_{0.05}$ & NS & NS \\
\hline \multirow[t]{5}{*}{4} & Amicarbazone & 0.1 & 100 & 100 \\
\hline & & 0.2 & 98 & 98 \\
\hline & & 0.4 & 102 & 102 \\
\hline & Bispyribac-sodium & 0.1 & 100 & 100 \\
\hline & & $\mathrm{LSD}_{0.05}$ & NS & NS \\
\hline \multirow[t]{8}{*}{6} & Amicarbazone & 0.1 & 100 & 98 \\
\hline & & 0.2 & 100 & 98 \\
\hline & & 0.4 & 102 & 102 \\
\hline & Bispyribac-sodium & 0.1 & 102 & 100 \\
\hline & & $\mathrm{LSD}_{0.05}$ & NS & NS \\
\hline & Treatment & & * & * \\
\hline & Timing & & * & * \\
\hline & Treatment $\times$ timing & & $*$ & * \\
\hline
\end{tabular}

${ }^{\mathrm{z}}$ Amicarbazone treatments included a non-ionic surfactant at $0.25 \% \mathrm{v} / \mathrm{v}$.

WBS $=$ weeks before seeding; LSD = least significant difference; $\mathrm{NS}=$ non-significant.

In Georgia, perennial ryegrass cover was reduced by $42 \%$ by amicarbazone at 0.4 $\mathrm{kg} \cdot \mathrm{ha}^{-1}$ or bispyribac-sodium applied the day of seeding by 4 WAS (Table 2). Reductions in perennial ryegrass cover (relative to the untreated control) for amicarbazone applied at 0.1 or $0.2 \mathrm{~kg} \cdot \mathrm{ha}^{-1}$ on the day of seeding measured less than $15 \%$ (Table 2). Similar results have been reported in Alabama and North Carolina when seeding creeping bentgrass and perennial ryegrass after amicarbazone applications at 0.1 or 0.2 $\mathrm{kg} \cdot \mathrm{ha}^{-1}$ (Walker, unpublished data; Yelverton, unpublished data). In Tennessee, bispyribac-sodium applied the day of seeding reduced perennial ryegrass cover 4 WAS by $56 \%$, which was significantly more than any rate of amicarbazone (Table 2). No differences in perennial ryegrass cover were detected 4 WAS for the three rates of amicarbazone applied the day of seeding in Tennessee (Table 2). Similar results were noted by 8 WAS in Tennessee with bispyribac-sodium significantly reducing perennial ryegrass cover to a greater degree than amicarbazone when applied the day of seeding.

\section{Discussion}

Responses in the current study illustrate that tall fescue and perennial ryegrass can be immediately reseeded into areas treated with amicarbazone at 0.1 or $0.2 \mathrm{~kg} \cdot \mathrm{ha}^{-1}$. Perennial
Hart, S. and P. McCullough. 2009. Mesotrione applications for annual bluegrass control during Kentucky bluegrass establishment. Agronomy Abstracts. CD-ROM. American Society of Agronomy, Madison, WI.

Johnson, B.J., G.W. Landry, and K.J. Karnok. 1989. Tolerance of bentgrass to amount, frequency, and timing of ethofumesate applications. HortScience 24:102-104.

Kaminski, J.A. and P.H. Dernoeden. 2007. Seasonal Poa аппиа L. seedling emergence patterns in Maryland. Crop Sci. 47:775-779.

Lush, W.M. 1989. Adaptation and differentiation of golf course populations of annual bluegrass. Weed Sci. 37:54-59.

Lycan, D.W. and S.E. Hart. 2005a. Cool-season turfgrass response to bispyribac-sodium. HortScience 40:1552-1555.

Lycan, D.W. and S.E. Hart. 2005b. Cool-season turfgrass reseeding intervals for sulfosulfuron. Applied Turfgrass Science (in press)

Lycan, D.W. and S.E. Hart. 2006a. Seasonal effects on annual bluegrass control in creeping bentgrass with bispyribac-sodium. Weed Technol. 20:722-727.

Lycan, D.W. and S.E. Hart. 2006b. Cool-season turfgrass reseeding intervals for bispyribacsodium. Weed Technol. 20:526-529.

Lycan, D.W., S.E. Hart, and J.A. Murphy. 2005. Annual bluegrass (Poa annua) control in Kentucky bluegrass (Poa pratensis) with sulfosulfuron. Intl. Turf. Soc. Res. J. 10:1222-1226.

McCullough, P.E. and S.E. Hart. 2006. Temperature influences creeping bentgrass (Agrostis palustris Huds.) and annual bluegrass (Poa апnиа L.) responses to bispyribac-sodium. Weed Technol. 20:728-732.

yegrass and tall fescue establishment appears uninhibited from amicarbazone at $0.4 \mathrm{~kg} \cdot \mathrm{ha}^{-1}$ when applied 2, 4, or $6 \mathrm{WBS}$, but this treatment may have potential to reduce cover when applied the day of seeding. The high rate of amicarbazone significantly reduced perennial ryegrass and tall fescue establishment in Georgia, comparable to bispyribac-sodium.

Given the enhanced efficacy and potential for reduced turf injury reported with spring applications of amicarbazone (McCullough et al., 2010; Yelverton, 2008), practitioners could selectively control annual bluegrass populations with amicarbazone in spring and safely reseed perennial ryegrass or tall fescue into voids remaining after annual bluegrass has been eradicated 2, 4, or 6 weeks after application. Amicarbazone at 0.1 to $0.2 \mathrm{~kg} \cdot \mathrm{ha}^{-1}$ may also have potential for annual bluegrass control during cool-season turfgrass establishment from seed. Further research should investigate seedling tolerance to amicarbazone rates and application regimes required for effective annual bluegrass control.

\section{Literature Cited}

Anonymous, 2004. Velocity® product label. Valent U.S.A. Corporation, Walnut Creek, CA

Beard, J.B. 1970. An ecological study of annual bluegrass. USGA Green Sect. Rec. 8:13-18.

Beard, J.B., P.E. Rieke, A.J. Turgeon, and J.M. Vargas. 1978. Annual bluegrass (Poa annua L.) description, adaptation, culture and control. Res. Rep. 352. Michigan.
McCullough, P.E. and S.E. Hart. 2009. Annual bluegrass control in perennial ryegrass and tall fescue with bispyribac-sodium. Applied Turfgrass Science doi:10.1094/ATS-2009-0508-01-RS.

McCullough, P.E., S.E. Hart, D. Weisenburger, and Z. Reicher. 2010. Amicarbazone efficacy on annual bluegrass and safety to cool-season turfgrasses. Weed Technol. (in press).

McCullough, P.E. and W. Nutt. 2010. Bermudagrass reseeding intervals for rimsulfuron, simazine, and sulfosulfuron. HortScience 45:693-695.

McIntosh, M.S. 1983. Analysis of combined experiments. Agron. J. 75:153-155.

Senseman, S.A. (ed.). 2007. Herbicide handbook. Weed Science Society of America, Lawrence, KS, p. 128.

Sprague, H.B. and G.W. Burton. 1937. Annual bluegrass (Poa annua L.), and its requirements for growth. New Jersey Agr. Experiment Station Bulletin 630. New Brunswick, NJ, p. 1-24.

Willis, J.B., D.B. Ricker, and S.D. Askew. 2007. establishment of seeded bermudagrass. Weed Technol. 21:1035-1038.

Yelverton, F. 2008. Spring transition from perennial ryegrass to bermudagrass and Poa аппиа management. $<$ http://www.turffiles.ncsu.edu/PDFFiles/ 004633/Southern_California_Golf_Course_ Superintedents_Association,_Manhattan_Beach_ CA.pdf $>$.

Yelverton, F.H., J.A. Hoyle, T.W. Gannon, and L.S. Warren. 2009. Plant counts, digital image analysis, and visual ratings for estimating weed control in turf: Are they correlated? Proc. South Weed Sci. Soc. 62:399. Sulfonylurea herbicides applied during early 